\title{
社団法人日本表面科学会 設立総会議事録
}

1. 開催日時; 平成 20 年 5 月 10 日（土） $15 ： 00 \sim 15: 40$ 開催場所 ; 東京大学 山上会館 大会議室

$$
\text { T113-8654 文京区本郷 7-3-1 }
$$

2. 正会員数； 1,314 名

3. 出席者の人数 854 名; 出席者数 39 名, 委任状数 815 名

4. 議事

開会時の司会を担当した福井賢一氏から，上記のような出席 者数をもって，本設立総会が有効に成立したことが報告され た。

（1）議長の選任の件

司会者が第 1 号議案「議長の選出」について諮ったと ころ, 岩澤康裕氏が推薦され, 可否を謥ったところ満 場一致で岩澤康裕氏が議長として選任された。

第 2 号議案から第 6 号議案の審議に入るにあたり，書 類の軽微な修正は第 7 号議案で選任する設立代表者へ 一任することが議長より提案され，満場一致で承認さ れた。

（2）社団法人日本表面科学会 設立に関する件 議長より, 社団法人化に至る経緯が報告され, 設立趣 意書の内容・趣旨が説明された。第 2 号議案として, この設立趣意書に基づき社団法人 日本表面科学会を 設立することについて可否を諮ったところ，満場一致 で可決された。

（3）定款に関する件

議長の指名により，福井賢一氏から定款の内容につい て説明された。第 3 号議案として, 議長よりこれを諮 ったところ，満場一致で承認された。
（4）寄附財産に関する件

議長の指名により，大岩 烈氏から財産目録の内容に ついて説明された。第 4 号議案として，議長より，こ の設立総会の結果をもって文部科学省に設立許可申請 を行い，文部科学大臣から設立許可があった時点をも って, 従来の日本表面科学会が持っていた財産は社団 法人日本表面科学会が継承するとともに，その時点で 作成される財産目録の通りの構成となることが㕠ら れ，満場一致でこれを可決した。

（5）事業計画及び予算に関する件 議長の指名により, 福井賢一氏から事業計画の内容に ついて，大岩 烈氏から予算について説明された。第 5 号議案として, 議長よりこれを諮ったところ, 満場 一致で承認された。

（6）役員に関する件

議長の指名により, 福井賢一氏から役員名簿について 説明された。第 6 号議案として, 議長より, 名簿を最 新の情報に更新することを条件に，役員の可否につい て諮ったところ, 満場一致で承認された。

（７）設立代表者選任に関する件

議長より設立代表者に委任する権限について説明され たのち，設立代表者として高柳邦夫氏が推薦された。 第 7 号議案として, 議長より高柳邦夫氏を設立代表者 とすること，設立代表者権限承諾書に記されている権 限を委任することが垫られ，満場一致で承認された。

（8）議事録署名人選任に関する件 議長より議事録署名人の選任について説明されたの ち，議事録署名人として吉原一紘氏および塚田 捷氏 が推薦された。第 8 号議案として, 議長よりこれを諮 ったところ，満場一致で承認された。 
財 産 目 録

平成 20 年 5 月 10 日現在

\begin{tabular}{|c|c|c|c|c|c|}
\hline & & 科 & & 額 & \\
\hline 1. 資産の部 & & & & & \\
\hline 1. 流動資産 & & & & & \\
\hline 現金預金 & & & & & \\
\hline 現金 & & 現金手元残高 & 140,675 & & \\
\hline 郵便振替貯金 & & 本郷四局 160-6-84613 & $2,620,960$ & & \\
\hline & & 本郷局 140-4-5161 & 179,020 & & \\
\hline & & 本郷局 150-7-5390 & 3,620 & & \\
\hline 普通預金 & & みずほ銀行本郷支店 & $9,924,166$ & & \\
\hline & & りそな銀行本郷支店 & 43,292 & & \\
\hline & & 三菱東京 UFJ 銀行本郷支店 & 40,100 & & \\
\hline 支部現金預金 & 関西支部 & 三井住友銀行北須磨支店 & 859,768 & & \\
\hline & 中部支部 & スルガ銀行浜松追分支店 & 22,206 & & \\
\hline & & 現金手元残高 & 6,609 & & \\
\hline & 東北支部 & 仙台銀行中央通支店 & 662,322 & & \\
\hline 未収会費 & & H18 年度会費 29 口, H19 年度会費 105 口 & 955,000 & & \\
\hline 未収入金 & & 別刷代金 8 口，広告料 4 口 & $1,596,000$ & & \\
\hline 流動資産合 & & & & $17,053,738$ & \\
\hline 2. 固定資産 & & & & & \\
\hline （1）基本財産 & & & & & \\
\hline 定期預金 & & りそな銀行本郷支店 & $10,000,000$ & & \\
\hline & & 三菱東京 UFJ 銀行本郷支店 & $10,000,000$ & & \\
\hline 基本財産合 & & & $20,000,000$ & & \\
\hline （2）特定資産 & & & & & \\
\hline 30 周年記念事 & 準備金引当預金 & みずほ銀行本郷支店 & $4,168,785$ & & \\
\hline 国際会議準備 & 引当預金 & みずほ銀行本郷支店 & $3,500,000$ & & \\
\hline 法人化準備金 & |当預金 & みずほ銀行本郷支店 & $2,606,692$ & & \\
\hline 若手育成基金 & |当預金 & みずほ銀行本郷支店 & $1,100,000$ & & \\
\hline 退職給与引当 & & みずほ銀行本郷支店 & 450,000 & & \\
\hline 学会誌刊行事 & 基金引当資産 & みずほ銀行本郷支店 & $6,000,000$ & & \\
\hline 特定資産合 & & & $17,825,477$ & & \\
\hline （3） その他の & 目定資産 & & & & \\
\hline 什器備品 & & & 803,960 & & \\
\hline 減価償却累計 & & & $-654,007$ & & \\
\hline 電話加入権 & & 電話架設費 & 81,283 & & \\
\hline 差入保証金 & & 事務所, 倉庫借上敷金 & $1,355,000$ & & \\
\hline その他の固 & 資産合計 & & $1,586,236$ & & \\
\hline 固定資産合 & & & & $39,411,713$ & \\
\hline 資産合計 & & & & & $56,465,451$ \\
\hline 2. 負債の部 & & & & & \\
\hline 1. 流動負債 & & & & & \\
\hline 前受金 & & $\mathrm{H} 21$ 年度会費 10 口 & 102,000 & & \\
\hline $\begin{array}{c}\text { 流動負債合 } \\
\text { 2. 固定負債 }\end{array}$ & & & & 102,000 & \\
\hline 30 周年記念事 & 業準備金引当金 & & $4,168,785$ & & \\
\hline 国際会議準備 & 会引当金 & & $3,500,000$ & & \\
\hline 法人化準備金 & I当金 & & $2,606,692$ & & \\
\hline 若手育成基金 & I当金 & & $1,100,000$ & & \\
\hline 退職給与引当 & & & 450,000 & & \\
\hline 学会誌刊行事 & 基基金引当金 & & $6,000,000$ & & \\
\hline 固定負債合 & & & & $17,825,477$ & \\
\hline 負債合計 & & & & & $17,927,477$ \\
\hline 正味財産 & & & & & $38,537,974$ \\
\hline
\end{tabular}




\section{平成 20 年度事業計画書}

設立許可日～2009年 3 月

1. 学術講演大会, 研究会等の開催（第 1 号事業）

1.1 特別講演会（設立総会）

「酸化物半導体を用いた太陽光エネルギー変換」荒川 裕則教授（東京理科大学工学部）

2008 年 5 月 10 日, 東京大学山上会館

1.2 第 28 回表面科学講演大会

2008 年 11 月 13 日 15 日, 早稲田大学総合学術情報 センター

*特別講演・招待講演・シンポジウム講演・一般講演

*受賞記念講演 (論文賞・会誌賞・奨励賞・技術賞)

*部会セッション

*講演奨励賞 (若手研究者部門, スチューデント部門) の選考

1.3 基礎講座

*第 45 回表面科学基礎講座「表面・界面分析の基礎と 応用」

2008 年 7 月 2 日 4 日, 東京大学小柴記念館

*第 46 回表面科学基礎講座「表面・界面分析の基礎と 応用」

2008 年 10 月 1 日～2 日，神戸大学瀧川記念学術交流 会館

* 第 11 回薄膜基礎講座 2008 年 9 月, 東京大学山上会 館

1.4 セミナー

*第 29 回表面科学セミナー 2008 年 10 月，東京大学山 上会館

1.5 研究会

* 第 59 回表面科学研究会「高機能薄膜の創製と展開」 (平成 20 年度関西支部セミナー)

2008 年 12 月, (株)島津製作所関西支社 マルチホー ル

*第 60 回表面科学研究会（平成 20 年度中部表面科学シ ンポジウム）2009年 1 月

*第 61 回表面科学研究会 (真空協会と合同研究会) 2009 年 2 月, 機械振興会館

*第 62 回表面科学研究会 2009 年 3 月

(関西支部主催)

*関西支部特別講演会 2008 年 5 月 30 日，(株)島津製 作所関西支社 マルチホール

*関西合同セミナー 2008「21 世紀に輝くダイヤモンド 一ナノダイヤの形成・機能の最先端一」(真空協会関 西支部との合同） 2008 年 7 月，神戸大学

* 第 11 回実用表面分析セミナー「実用表面分析」 2008 年 10 月 3 日, 神戸大学百年記念館

*表面科学技術研究会 2009（表面技術協会関西支部と の合同開催)

2009 年 1 月 23 日，神戸大学瀧川記念学術交流会館

(中部支部主催)

*中部支部研究会 2008 年 11 月，静岡大学

*中部支部学術講演会「若手講演会」2008 年 12 月

(東北・北海道支部)

*東北・北海道支部講演会 2009 年 3 月

1.6 第 5 回国際シンポジウム「表面科学とナノテクノロジ 一に関する国際シンポジウム (ISSS-5)」

2008 年 11 月 9 日〜 13 日, 早稲田大学総合学術情報セ ンター

1.7 市民講座

*第 9 回本部市民講座・サイエンスカフェ「体の表面を 科学する
2008 年 8 月 9 日（土）, 東京大学山上会館

* 第 10 回関西支部市民講座「体の表面を科学する」

2009 年 2 月 28 日または 3 月 7 日，大阪市立大学文化 交流センター

*中部支部市民講座「体の表面を科学する」

2008 年 8 月 2 日, 名古屋工業大学

2. 学会誌及び学術図書の刊行 (第 2 号事業)

2.1 会誌「表面科学」

*会誌「表面科学」の刊行

*電子版「表面科学」の刊行

2.2 電子ジャーナル「E-Journal of Surface Science and Nano Technology」

*通常論文の公開出版

*各種国際シンポジウムプロシーディングス論文集の刊

行 (Handai Nano, ALC07, ISSS-5, ICSFS-14)

*解説論文, 原著論文等執筆依頼の強化

* J-Stage との連絡調整

3. 表面科学に関する調查研究及び研究成果の公開（第 3 号事 業)

3.1 バーチャル表面科学・ナノテクノロジー博物館の開設

3.2 表面分析事例のデータベース公開

4. 研究の奨励及び研究業績の表彰 (第 4 号事業)

*名誉会員, 功労会員の推薦

*学会賞, 功績賞候補者の推䳸

*学会賞・功績賞の贈呈

*論文賞・会誌賞・奨励賞・技術賞候補者の推薦および 選定

*論文賞・会誌賞・奨励賞・技術賞の贈呈

*講演奨励賞（若手研究者部門，スチューデント部門） の選考（論文賞等選定委員会と合同）

*講演奨励賞（若手研究者部門，スチューデント部門） の贈呈

5. 内外の関連学協会等との交流及び研究協力 (第 5 号事業 $)$

5.1 中学・高校向け教育用教材の配布

5.2 JABEE

* JABEE 総会・連絡協議会等に参加

*「物理・応用物理分野審査委員会」に参加

6. その他目的を達成するために必要な事業（第 6 号事業）

6.1 理事会で認められた事業

*各種委員会等での検討をもとに理事会で承認した事業

\section{平成 21 年度事業計画書}

2009 年 4 月～ 2010 年 3 月

1. 学術講演大会, 研究会等の開催（第 1 号事業）

1.1 特別講演会（通常総会） 2009 年 5 月，関東

1.2 第 29 回表面科学講演大会 2009 年 11 月, 関東 *特別講演・招待講演・シンポジウム講演・一般講演

*受賞記念講演 (学会賞・論文賞・会誌賞・奨励賞・技 術賞)

*部会セッション

*講演奨励賞（若手研究者部門，スチューデント部門） の選考

1.3 基礎講座

* 第 47 回表面科学基礎講座「表面 - 界面分析の基礎と 応用」 2009 年 7 月, 東京

*第 48 回表面科学基礎講座「表面 - 界面分析の基礎と 応用」 2009 年 10 月，関西

*第 12 回薄膜基礎講座 2009 年 9 月，東京

1.4 セミナー

*第 30 回表面科学セミナー 2009 年 10 月，東京

1.5 研究会

* 第 63 回表面科学研究会 (平成 21 年度関西支部セミナ 
一） 2009 年 12 月, 関西

*第 64 回表面科学研究会 (平成 21 年度中部表面科学 ンポジウム） 2010 年 1 月, 中部

*第 65 回表面科学研究会 (真空協会と合同研究会) 2010 年 2 月, 機械振興会館

*第 66 回表面科学研究会 2010 年 3 月

(関西支部主催)

*関西合同セミナー 2009（真空協会関西支部との合同） 2009 年 7 月, 関西

*第 12 回実用表面分析セミナー「実用表面分析」 2009 年 10 月, 関西

*表面科学技術研究会 2010 (表面技術協会関西支部と の合同開催） 2010 年 1 月，関西

(中部支部主催)

*中部支部研究会 2009 年 11 月, 中部

*中部支部学術講演会「若手講演会」 2009 年 12 月

(東北・北海道支部主催)

$*$ 東北・北海道支部講演会 2010 年 3 月

1.6 第 6 回国際シンポジウム

*組織実行委員会の立ち上げ「表面科学とナノテクノロ ジーに関する国際シンポジウム（ISSS-6）」 2011 年

1.7 市民講座

*第 10 回本部市民講座・サイエンスカフェ 2009 年 8 月，東京

*第 11 回関西支部市民講座 2010 年 3 月，関西

*中部支部市民講座 2009 年 8 月，中部

2. 学会誌及び学術図書の刊行（第 2 号事業）

2.1 会誌「表面科学」

*会誌「表面科学」の刊行

*電子版「表面科学」の刊行

2.2 電子ジャーナル「E-Journal of Surface Science and Nano Technology」

*通常論文の公開出版

*各種国際シンポジウムプロシーディングス論文集の刊 行

*解説論文，原著論文等執筆依頼の強化

* J-Stage との連絡調整

3. 表面科学に関する調查研究及び研究成果の公開（第 3 号事 業)

3.1 バーチャル表面科学・ナノテクノロジー博物館の開設

3.2 表面分析事例のデータベース公開

4. 研究の奨励及び研究業績の表彰（第 4 号事業）

*名誉会員, 功労会員の推薦

* 学会賞, 功績賞候補者の推薦

*学会賞・功績賞の贈呈

*論文賞・会誌賞・奨励賞・技術賞候補者の推薦抒よび 選定

*論文賞・会誌賞・奨励賞・技術賞の贈呈

*講演奨励賞（若手研究者部門，スチューデント部門） の選考

*講演奨励賞（若手研究者部門，スチューデント部門） の贈呈

5. 内外の関連学協会等との交流及び研究協力（第 5 号事業）

5.1 中学・高校向け教育用教材の配布

*中学・高校向け教育用教材の作成

5. 2 JABEE

* JABEE 総会・連絡協議会等に参加

*「物理・応用物理分野審査委員会」に参加

6. その他目的を達成するために必要な事業（第 6 号事業）

6.1 理事会で認められた事業

*各種委員会等での検討をもとに理事会で承認した事業
平成 22 年度事業計画書

2010 年 4 月～ 2011 年 3 月

1. 学術講演大会，研究会等の開催（第 1 号事業）

1.1 特別講演会（通常総会） 2010 年 5 月，関東

1.2 第 30 回表面科学講演大会 2010 年 11 月, 関西 *特別講演・招待講演・シンポジウム講演・一般講演

*受賞記念講演 (学会賞 · 論文賞 · 会誌賞 · 奨励賞 · 技 術賞)

*部会セッション

*講演奨励賞（若手研究者部門，スチューデント部門） の選考

1.3 基礎講座

* 第 49 回表面科学基碟講座「表面 - 界面分析の基礎と 応用」 2010 年 7 月, 東京

* 第 50 回表面科学基礎講座「表面 - 界面分析の基礎と 応用」 2010 年 10 月, 関西

* 第 13 回薄膜基礎講座 2010 年 9 月，東京

1.4 セミナー

*第 31 回表面科学セミナー 2010 年 10 月，東京

1.5 研究会

* 第 67 回表面科学研究会 (平成 22 年度関西支部セミナ 一） 2010 年 12 月, 関西

* 第 68 回表面科学研究会 (平成 22 年度中部表面科学シ ンポジウム） 2011 年 1 月, 中部

*第 69 回表面科学研究会 (真空協会と合同研究会) 2011 年 2 月, 機械振興会館

*第 70 回表面科学研究会 2011 年 3 月

(関西支部主催)

*関西合同セミナー 2010（真空協会関西支部との合同） 2010 年 7 月, 関西

*第 13 回実用表面分析セミナー「実用表面分析」 2010 年 10 月, 関西

*表面科学技術研究会 2011 (表面技術協会関西支部と の合同開催） 2011 年 1 月，関西

（中部支部主催）

*中部支部研究会 2010 年 11 月，中部

*中部支部学術講演会「若手講演会」 2010 年 12 月

(東北・北海道支部主催)

*東北・北海道支部講演会 2011 年 3 月

1.6 第 6 回国際シンポジウム

*会議準備「表面科学とナノテクノロジーに関する国際 シンポジウム（ISSS-6）」 2011 年

1.7 市民講座

*第 11 回本部市民講座・サイエンスカフェ 2010 年 8 月, 東京

* 第 12 回関西支部市民講座 2011 年 3 月，関西

*中部支部市民講座 2010 年 8 月, 中部

2. 学会誌及び学術図書の刊行（第 2 号事業）

2.1 会誌「表面科学」

*会誌「表面科学」の刊行

*電子版「表面科学」の刊行

2.2 電子ジャーナル「E-Journal of Surface Science and Nano Technology」

*通常論文の公開出版

*各種国際シンポジウムプロシーディングス論文集の刊 行

*解説論文，原著論文等執筆依頼の強化

* J-Stage との連絡調整 
3. 表面科学に関する調査研究及び研究成果の公開（第 3 号事 業)

3.1 バーチャル表面科学・ナノテクノロジー博物館の開設

3.2 表面分析事例のデータベース公開

4. 研究の奨励及び研究業績の表彰 (第 4 号事業)

*名誉会員, 功労会員の推薦

*学会賞, 功績賞候補者の推薦

*学会賞・功績賞の贈呈

*論文賞・会誌賞・奨励賞・技術賞候補者の推薦および 選定

*論文賞・会誌賞・奨励賞・技術賞の贈呈

*講演奨励賞 (若手研究者部門, スチューデント部門)
の選考

*講演奨励賞（若手研究者部門，スチューデント部門） の贈呈

5. 内外の関連学協会等との交流及び研究協力 (第 5 号事業 $)$

5.1 中学・高校向け教育用教材の配布 *中学・高校向け教育用教材の作成

5. 2 JABEE

* JABEE 総会・連絡協議会等に参加

*「物理・応用物理分野審查委員会」に参加

6. その他目的を達成するために必要な事業（第 6 号事業）

6. 1 理事会で認められた事業

*各種委員会等での検討をもとに理事会で承認した事業 
設立後 3 事業年度分の収支予算書

設立許可日～平成 23 年 3 月

\begin{tabular}{|c|c|c|c|c|}
\hline 科 & 平成 20 年度 & 平成 21 年度 & 平成 22 年度 & 備考 \\
\hline \multicolumn{5}{|l|}{ I. 事業活動収支の部 } \\
\hline \multicolumn{5}{|l|}{ 1. 事業活動収入 } \\
\hline (1)基本財産運用収入 & 10,000 & 10,000 & 10,000 & \\
\hline 基本財産利息収入 & 10,000 & 10,000 & 10,000 & \\
\hline (2)会費収入 & $3,705,000$ & $17,753,000$ & $17,753,000$ & \\
\hline 正会員会費収入 & $2,597,000$ & $12,240,000$ & $12,240,000$ & \\
\hline 学生会員会費収入 & 228,000 & 513,000 & 513,000 & \\
\hline 維持会員会費収入 & 300,000 & 800,000 & 800,000 & \\
\hline 賛助会員会費収入 & 240,000 & $3,000,000$ & $3,000,000$ & \\
\hline 購読会員会費収入 & 340,000 & $1,200,000$ & $1,200,000$ & \\
\hline (3)事業収入 & $43,482,976$ & $26,360,000$ & $26,460,000$ & \\
\hline 学術講演大会 - 研究会等事業収入 & $28,795,000$ & $12,300,000$ & $12,300,000$ & \\
\hline 講演大会参加費等収入 & $2,100,000$ & $2,100,000$ & $2,100,000$ & \\
\hline 基礎講座参加費等収入 & $6,245,000$ & $6,600,000$ & $6,600,000$ & \\
\hline 研究会参加費等収入 & 200,000 & 200,000 & 200,000 & \\
\hline セミナー参加費等収入 & $1,400,000$ & $1,400,000$ & $1,400,000$ & \\
\hline 国際会議参加費等収入 & $16,850,000$ & 0 & 0 & \\
\hline 支部研究会参加費等収入 & $2,000,000$ & $2,000,000$ & $2,000,000$ & \\
\hline 学会誌・学術図書刊行事業収入 & $14,587,976$ & $13,810,000$ & $13,810,000$ & \\
\hline e-journal 投稿料収入 & $2,490,000$ & 500,000 & 500,000 & \\
\hline 別刷頒布代収入 & $4,204,000$ & $4,500,000$ & $4,500,000$ & \\
\hline 会誌頒布収入 & $1,598,400$ & $1,800,000$ & $1,800,000$ & \\
\hline 出版物頒布収入 & 59,000 & 60,000 & 60,000 & \\
\hline 著作権料・複写代収入 & 150,000 & 150,000 & 150,000 & \\
\hline 学会出版物印税収入 & 296,076 & 300,000 & 300,000 & \\
\hline 広告料収入 & $5,790,500$ & $6,500,000$ & $6,500,000$ & \\
\hline 調査・研究事業収入 & 50,000 & 200,000 & 300,000 & \\
\hline 交流・協力事業収入 & 50,000 & 50,000 & 50,000 & \\
\hline (4)寄付金収入 & $56,363,451$ & 0 & 0 & $※ 1$ \\
\hline 寄付金収入 & $56,363,451$ & 0 & 0 & \\
\hline (5)雑収入 & 96,845 & $1,110,000$ & 110,000 & \\
\hline 名簿頒布収入 & 93,000 & $1,100,000$ & 100,000 & \\
\hline 受取利息収入 & 3,845 & 10,000 & 10,000 & \\
\hline 事業活動収入計 & $103,658,272$ & $45,233,000$ & $44,333,000$ & \\
\hline \multicolumn{5}{|l|}{ 2. 事業活動支出 } \\
\hline 学術講演大会 - 研究会等事業費 & $29,290,912$ & $13,070,000$ & $13,070,000$ & \\
\hline 特別講演会運営費支出 & 99,892 & 420,000 & 420,000 & \\
\hline 講演大会運営費支出 & $2,000,000$ & $2,000,000$ & $2,000,000$ & \\
\hline 基礎講座運営費支出 & $4,757,623$ & $5,000,000$ & $5,000,000$ & \\
\hline 研究会運営費支出 & 700,000 & 700,000 & 700,000 & \\
\hline セミナー運営費支出 & 892,030 & 950,000 & 950,000 & \\
\hline 国際会議運営費支出 & $16,850,000$ & 0 & 0 & \\
\hline 支部研究会運営費支出 & $2,991,367$ & $3,000,000$ & $3,000,000$ & \\
\hline 市民講座運営費支出 & 800,000 & 800,000 & 800,000 & \\
\hline 研究部会費支出 & 200,000 & 200,000 & 200,000 & \\
\hline 学会誌・学術図書刊行事業費 & $15,802,292$ & $17,402,000$ & $17,402,000$ & \\
\hline 会誌編集等委託・印刷費支出 & $12,094,602$ & $13,352,000$ & $13,352,000$ & \\
\hline 別刷印刷・製本代支出 & 573,015 & 600,000 & 600,000 & \\
\hline 発送費支出 & $1,925,781$ & $2,100,000$ & $2,100,000$ & \\
\hline 原稿料支出 & 838,894 & 950,000 & 950,000 & \\
\hline 英文校正料支出 & 370,000 & 400,000 & 400,000 & \\
\hline 調査・研究事業費 & 200,000 & 300,000 & 300,000 & \\
\hline 研究奨励・研究業績表彰事業費 & 230,000 & 230,000 & 230,000 & \\
\hline 交流・協力事業費 & 120,000 & 320,000 & 320,000 & \\
\hline 教育用教材製作費支出 & 100,000 & 200,000 & 200,000 & \\
\hline
\end{tabular}




\begin{tabular}{|c|c|c|c|}
\hline 技術者教育関係費支出 & 20,000 & 120,000 & 120,000 \\
\hline その他事業費 & 100,000 & 100,000 & 100,000 \\
\hline 事業費支出計 & $45,743,204$ & $31,422,000$ & $31,422,000$ \\
\hline \multicolumn{4}{|l|}{ (2)管理費支出 } \\
\hline 給与手当支出 & $5,326,598$ & $6,000,000$ & $6,000,000$ \\
\hline 福利厚生費支出 & 860,000 & 860,000 & 860,000 \\
\hline 旅費交通費支出 & 447,670 & 600,000 & 600,000 \\
\hline 退職金共済積立支出 & 110,000 & 120,000 & 120,000 \\
\hline 会議費支出 & 130,000 & 130,000 & 130,000 \\
\hline 通信運搬費支出 & 951,295 & $1,000,000$ & $1,000,000$ \\
\hline 印刷製本費支出 & 490,028 & 500,000 & 500,000 \\
\hline 事務局賃借料支出 & $2,199,500$ & $2,420,000$ & $2,420,000$ \\
\hline 名簿刊行費支出 & 50,000 & 500,000 & 50,000 \\
\hline 委員会費支出 & 389,310 & 400,000 & 400,000 \\
\hline 雑費支出 & $1,108,585$ & $1,300,000$ & $1,300,000$ \\
\hline 管理費支出計 & $12,062,986$ & $13,830,000$ & $13,380,000$ \\
\hline 事業活動支出計 & $57,806,190$ & $45,252,000$ & $44,802,000$ \\
\hline 事業活動収支差額 & $45,852,082$ & $-19,000$ & $-469,000$ \\
\hline \multicolumn{4}{|l|}{ II. 投資活動収支の部 } \\
\hline \multicolumn{4}{|l|}{ 1. 投資活動収入 } \\
\hline (1)特定資産取崩収入 & $9,300,000$ & $6,800,000$ & $6,800,000$ \\
\hline 市民講座積立資産取崩収入 & 800,000 & 800,000 & 800,000 \\
\hline 学会誌等刊行事業積立資産取崩収入 & $6,000,000$ & $6,000,000$ & $6,000,000$ \\
\hline 国際会議積立資産取崩収入 & $2,500,000$ & 0 & 0 \\
\hline 投資活動収入計 & $9,300,000$ & $6,800,000$ & $6,800,000$ \\
\hline \multicolumn{4}{|l|}{ 2. 投資活動支出 } \\
\hline (1)基本財産取得支出 & $20,000,000$ & 0 & 0 \\
\hline 基本財産繰入支出 & $20,000,000$ & 0 & 0 \\
\hline (2)特定資産取得支出 & $25,385,477$ & $6,060,000$ & $6,060,000$ \\
\hline 退職給付引当資産取得支出 & 510,000 & 60,000 & 60,000 \\
\hline 30 周年記念事業積立資産取得支出 & $4,168,785$ & 0 & 0 \\
\hline 市民講座積立資産取得支出 & $2,606,692$ & 0 & 0 \\
\hline 学会誌等刊行事業積立資産取得支出 & $12,000,000$ & $6,000,000$ & $6,000,000$ \\
\hline 国際会議積立資産取得支出 & $5,000,000$ & 0 & 0 \\
\hline 若手育成積立資産取得支出 & $1,100,000$ & 0 & 0 \\
\hline ３その他固定資産支出 & $1,590,186$ & 0 & 0 \\
\hline 什器備品取得支出 & 153,903 & 0 & 0 \\
\hline 電話加入権取得支出 & 81,283 & 0 & 0 \\
\hline 差入保証金取得支出 & $1,355,000$ & 0 & 0 \\
\hline 投資活動支出計 & $46,975,663$ & $6,060,000$ & $6,060,000$ \\
\hline 投資活動収支差額 & $-37,675,663$ & 740,000 & 740,000 \\
\hline \multicolumn{4}{|l|}{ III. 財務活動収支の部 } \\
\hline III. 予備費支出 & 100,000 & 100,000 & 100,000 \\
\hline 当期収支差額 & $8,076,419$ & 621,000 & 171,000 \\
\hline 前期繰越収支差額 & 0 & $8,076,419$ & $8,697,419$ \\
\hline 次期繰越収支差額 & $8,076,419$ & $8,697,419$ & $8,868,419$ \\
\hline
\end{tabular}

注 1 寄付金は(任意団体)日本表面科学会からの寄付 寄付金収入 $¥ 56,363,451$ の内訳 基本財産

20,000,000 特定財产

30 周年記念事業準備金引当資産 $4,168,785$ 国際会議準備金引当資産 $3,500,000$ 市民講座準備金引当資産 $2,606,692$ 若手育成基金引当資産 $1,100,000$ 退職給付引当資産 450,000 学会誌刊行事業基金引当資産 6,000,000 運用財産 
社団法人 日本表面科学会 役員名簿

\begin{tabular}{|c|c|c|c|c|c|c|}
\hline 役職 & & 氏 & 名 & 現 職 & 常勤・非常勤 & 備考 \\
\hline & & 高柳 & 邦夫 & 東京工業大学大学院理工学研究科教授 & 非常勤 & \\
\hline 副会 & & 吉原 & 一紘 & アルバック・ファイ(株)理事(技術顧問) & 非常勤 & \\
\hline 理 & 事 & 大岩 & 烈 & オミクロン ナノテクノロジージャパン(株)代表取締役社長 & 非常勤 & \\
\hline 理 & 事 & 太田 & 英二 & 慶応義塾大学理工学部教授 & 非常勤 & \\
\hline 理 & 事 & 荻野 & 俊郎 & 横浜国立大学大学院工学研究院教授 & 非常勤 & \\
\hline 理 & 事 & 蒲生 & 美香 & 東洋大学工学部准教授 & 非常勤 & \\
\hline 理 & 事 & 木村 & 健二 & 京都大学大学院工学研究科教授 & 非常勤 & \\
\hline 理 & 事 & 工藤 & 正博 & 成蹊大学理工学部教授 & 非常勤 & \\
\hline 理 & 事 & 近藤 & 寛 & 慶應義塾大学理工学部教授 & 非常勤 & \\
\hline 理 & 事 & 須藤 & 彰三 & 東北大学大学院理学研究科教授 & 非常勤 & \\
\hline 理 & 事 & 大門 & 寛 & 奈良先端科学技術大学院大学物質創成科学研究科教授 & 非常勤 & \\
\hline 理 & 事 & 田部 & 道晴 & 静岡大学電子工学研究所教授 & 非常勤 & \\
\hline 理 & 事 & 玉田 & 董 & 東北大学電気通信研究所教授 & 非常勤 & \\
\hline 理 & 事 & 中村 & 友二 & (株)富士通研究所基盤技術研究所所長代理 & 非常勤 & \\
\hline 理 & 事 & 橋詰 & 富博 & (株)日立製作所基礎研究所主任研究員 & 非常勤 & \\
\hline 理 & 事 & 長谷川 & |修司 & 東京大学大学院理学系研究科准教授 & 非常勤 & \\
\hline 理 & 事 & 福井 & 賢一 & 大阪大学大学院基礎工学研究科教授 & 非常勤 & \\
\hline 理 & 事 & 森田 & 清三 & 大阪大学大学院工学研究科教授 & 非常勤 & \\
\hline 理 & 事 & 渡辺 & 一之 & 東京理科大学理学部教授 & 非常勤 & \\
\hline 理 & 事 & 渡邊 & 聡 & 東京大学大学院工学系研究科教授 & 非常勤 & \\
\hline 監 & 事 & 岩澤 & 康裕 & 東京大学大学院理学系研究科教授 & 非常勤 & \\
\hline 監 & 事 & 一宮 & 彪彦 & 日本女子大学特任教授 - 名古屋大学名誉教授 & 非常勤 & \\
\hline 監 & 事 & 染野 & 光宏 & 染野公認会計士事務所所長 & 非常勤 & \\
\hline
\end{tabular}

